\title{
KAJIAN POSKOLONIAL GERAKAN PEMIKIRAN DAN SIKAP ULAMA PESANTREN TEGALSARI DALAM PUSARAN KONFLIK MULTIDIMENSIONAL DI JAWA (1742-1862)
}

\author{
Saifuddin Alif Nurdianto, ${ }^{1}$ Hermanu Joebagio, ${ }^{2}$ Djono $^{3}$ \\ Pascasarjana Universitas Negeri Sebelas Maret \\ e-mail: 1saifuddinalif2@gmail.com, ${ }^{2}$ hermanu.joebagio@gmail.com, \\ 3djono_sk@yahoo.com
}

\begin{abstract}
Pesantren Tegalsari was one of the most influential religious-education institutions in Java during 18-19 century. Those years were the golden era of Pesantren Tegalsari which was known as an institution that produced "pujangga" (Javanese intellectuals) and the people of Tegalsari village was well known for producing high quality of dluwang (traditional paper). On the other hand, the 18-19 century itself was a time of turmoil, both socially and politically. Some events such as Geger Pacina (1742), Javanese Succession War III (1746-1755), Java War (18251830), and Cultuurstelsel (1830-1917) were crucial moments in the history of Indonesia, especially in Java. At this point, the ulema (Islamic scholars) of Pesantren Tegalsari played an important role. Thought and attitude movements of ulema (Islamic scholars) in Pesantren Tegalsari had determined the existence of the pesantren and the economic cycle of local commmunity. Historical research with post-colonial political approach was used to study the thought and attitude movement of ulama (Islamic scholars) in Pesantren Tegalsari during 1742-1862. The result of this research shows that Pesantren Tegalsari had a political line to not engage in practical politics. This political line was followed by all the leaders of Pesantren Tegalsari. As the result, Pesantren Tegalsari developed into an institution that produced poets and transformed into a place to seek legitimacy in social, academic, and politic.
\end{abstract}

\begin{abstract}
Abstrak: Pesantren Tegalsari merupakan salah satu lembaga pendidikankeagamaan yang paling berpengaruh di Jawa abad 18-19. Tahun-tahun tersebut merupakan masa keemasan dari Pesantren Tegalsari yang dikenal sebagai lembaga pencetak pujangga (intelektual Jawa). Bagi masyarakat Desa Tegalsari sendiri, tahun-tahun itu adalah masa perekonomian yang dikembangkan sedang mengalami pertumbuhan yang pesat. Desa Tegalsari terkenal sebagai daerah penghasil dluwang (kertas tradisional) berkualitas tinggi yang diekspor ke berbagai daerah. Di sisi yang lain, abad 18-19 sendiri merupakan masa yang penuh dengan gejolak, baik secara sosial maupun politik. Beberapa peristiwa seperti geger pacina (1742), Perang Suksesi Jawa III (1746-1755), Perang Jawa (1825-1830), dan kebijakan tanam paksa (1830-1917) merupakan momenmomen krusial dalam perjalanan sejarah Indonesia, khususnya di pulau Jawa. Pada titik inilah ulama Pesantren Tegalsari, sebagai salah satu pimpinan lembaga pendidikan-keagamaan paling berpengaruh di Jawa abad 18-19 sekaligus tokoh panutan bagi masyarakat sekitar, memiliki peranan penting. Gerakan pemikiran
\end{abstract}


dan sikap dari ulama Pesantren Tegalsari menjadi sangat menentukan eksistensi pesantren dan perputaran roda perekonomian masyarakat sekitar. Penelitian historis dengan pendekatan politik-poskolonial akan digunakan untuk mengkaji gerakan pemikiran dan sikap ulama Pesantren Tegalsari tahun 1742-1862. Hasil penelitian menunjukkan bahwa Pesantren Tegalsari memiliki garis politik untuk tidak terjun dalam politik praktis. Garis politik inilah yang diikuti oleh semua pimpinan Pesantren Tegalsari. Hasilnya adalah, Pesantren Tegalsari berkembang menjadi lembaga pencetak pujangga dan menjelma sebagai tempat untuk mencari legitimasi, baik secara sosial, akademik, maupun politik.

Keywords: gerakan pemikiran; ulama; Pesantren Tegalsari; gejolak politik; konflik multidimensional

\section{A. Pendahuluan}

Pesantren merupakan bentuk pendidikan-keagamaan indigenious Indonesia, yang telah hidup dalam budaya masyarakat Indonesia sejak jaman pra-aksara. Pesantren adalah lembaga pendidikan-keagamaan yang tumbuh dari bawah atau masyarakat itu sendiri. ${ }^{1}$ Model pendidikan pesantren selanjutnya identik dengan Islam seiring perkembangan Islam di Indonesia. Di sisi lain, tidak ada agama selain Islam yang mengembangkan pola pendidikan ala pesantren.

Salah satu pesantren tertua yang pernah berdiri di Indonesia adalah Pesantren Tegalsari. Pesantren Tegalsari didirikan oleh Kiai Ageng Mohamad Besari pada awal abad ke-18 dengan nama asli Pesantren Gebang Tinatar.2 Kiai Ageng Mohamad Besari memimpin Pesantren Tegalsari dari tahun 1742-1773 Dalam perjalanannya, pesantren ini kemudian lebih dikenal dengan nama Pesantren Tegalsari merujuk kepada letak geografisnya yang berada di Desa Tegalsari.

Pesantren Tegalsari berdiri di tengah konflik multidimensional yang terjadi di Jawa. Kiai Ageng Mohamad Besari, sebagai pimpinan Pesantren Tegalsari sekaligus ulama karismatik di Ponorogo, menjadi saksi pergolakan demi pergolakan terjadi pada tahun-tahun ketika dia memimpin pesantren. Ahmad Baso menjelaskan, keterlibatan Pesantren Tegalsari tidak lepas dari konsep jejer pandhita yang sering dijadikan pegangan oleh raja-raja Jawa. Konsep jejer pandhita berasal dari salah satu adegan dalam cerita pewayangan yang

${ }^{1}$ H.A.R. Tilaar, Paradigma Baru Pendidikan Nasional (Jakarta: Rineka Cipta, 2002), 151-153.

${ }^{2}$ Haris Daryono Ali Haji, Menggali Pemerintahan Negeri Doho, dari Majapahit menuju Pondok Pesantren, sebelum Walisongo dan Babad Pondok Tegalsari (Yogyakarta: Elmatera, 2016), 263. 
menceritakan pertemuan seorang tokoh protagonis (ksatria) dengan seorang guru spiritual (pandhita) yang menjadi pembimbingnya dalam menegakkan kebenaran. Dalam tradisi Jawa, jejer pandhita berarti menghadap kepada sang agamawan di kediamannya, yang biasanya terletak di daerah terpencil. Di daerah itu biasa ditemukan agamawan yang mendalami ilmu, baik makrifat maupun hakikat, yang akan diwariskan kepada muridnya. Dalam konteks ini, posisi pandhita (kiai, ulama) sebagai ideolog dikukuhkan, sementara sang ksatria bertindak sebagai eksekutor di lapangan. Di akhir kisah, sang eksekutor yang akan menjadi pahlawan. Gurunya tidak dikenal, tetapi posisinya jelas sebagai the man behind the gun atau aktor di balik tindakan sang pahlawan. Inilah yang terjadi dalam relasi antara kaum pesantren dan raja-raja Jawa. ${ }^{3}$

Konsep jejer pandhita terjadi di hampir semua kekuasaan di Jawa. Beberapa tokoh bisa dijadikan contoh, seperti Raden Patah jejer pandhita dengan Sunan Ampel,4 Jaka Tingkir jejer pandhita dengan Sunan Kalijaga, ${ }^{5}$ dan Panembahan Senopati jejer pandhita dengan Ki Juru Martani. ${ }^{6}$ Konsep ini pula yang kemudian melandasi Pakubuwana II untuk jejer pandhita kepada Kiai Ageng Mohamad Besari, pimpinan Pesantren Tegalsari.

Jejer pandhita yang dilakukan oleh kaum bangsawan terhadap seorang kiai tidak semata-mata karena posisi kiai sebagai tokoh spiritual. Relasi antara kaum bangsawan dan kiai terjadi karena pada dasarnya kiai termasuk golongan bangsawan. Artinya kiai-kiai besar, setidaknya sampai abad ke-18, secara genealogis merupakan keturunan bangsawan. ${ }^{7}$ Relasi inilah yang menyebabkan pesantren selalu terlibat, atau paling tidak berusaha dilibatkan oleh kaum aristokrat, dalam kontestasi politik sebuah kekuasaan.

${ }^{3}$ Ahmad Baso, "Akar Pendidikan Kewarganegaraan di Pesantren," Jurnal Pendidikan Islam 17, no. 2 (2012): 175-76., https://doi.org/10.15575/jpi.v27i2.503.

4Slamet Muljana, Runtuhnya Kerajaan Hindu-Jawa dan Timbulnya Negara-negara Islam di Nusantara (Yogyakarta: LKiS, 2005), 41.

${ }^{5}$ Laurie Jo Sears, Shadows of Empire: Colonial Discourse and Javanese Tales (London: Duke University Press, 1996), 54.

${ }^{6}$ Barbara Hatley, Javanese Performances on an Indonesian Stage: Celebrating Culture, Embracing Change (Singapore: NUS Press, 2008), 89.

7Sampai abad ke-18, setidaknya ada lima jenis lembaga pendidikan di Jawa, yaitu padepokan, asrama, dukuh, paguron, dan pesantren. Jadi keterlibatan pesantren dalam pusaran konflik tidak semata-mata karena institusi pendidikan yang diembannya, tetapi juga relasi genealogisnya dengan keraton. Hal ini berbeda dengan pandangan kaum orientalis yang menganggap kiai sama dengan pastor atau pendeta yang hanya seorang agamawan. Husni Sahal dan Alhafiz K., "Ini Penjelasan Agus Sunyoto tentang Hubungan Pesantren Dan Keraton," NU Online: Soeara Nahdlatoel Oelama, 2017, http://www.nu.or.id/post/read/79995/ini-penjelasan-agus-sunyoto-tentang-hubunganpesantren-dan-keraton. 
Konflik pertama yang melibatkan Pesantren Tegalsari adalah peristiwa geger pacina yang terjadi di Kasunanan Kartasura tahun 1742. Konflik yang mengakibatkan hancurnya Keraton Kartasura ini memaksa Pakubuwana II, sebagai Raja Mataram, melarikan diri dari keraton. Pesantren Tegalsari kemudian dipilih oleh sang Raja untuk dijadikan sebagai tempat pelariannya, sekaligus mencari ketenangan dengan bimbingan spiritual dari Kiai Ageng Mohamad Besari. 8

Konflik kedua adalah ketika pecah Perang Suksesi Jawa III (1746-1755). ${ }^{9}$ Pada perang yang akhirnya menyebabkan terpecahnya kekuasaan Jawa menjadi Kasunanan Surakarta dan Kasultanan Yogyakarta tersebut, Pesantren Tegalsari menjadi salah satu tempat yang dikunjungi oleh elit keraton yang sedang berkonflik guna meminta dukungan politik. Pangeran Mangkubumi dan Pangeran Singasari sebagai pihak oposisi dari Pakubuwana II datang kepada Kiai Ageng Mohamad Besari untuk meminta dukungan politik dalam upayanya memisahkan diri dari Kasunanan Surakarta. ${ }^{10}$ Tidak ada bukti yang menyatakan dukungan Kiai Ageng Mohamad Besari kepada Pangeran Mangkubumi dan Pangeran Singasari, tetapi upaya kedua pangeran untuk mencari dukungan politik kepada sang Kiai menunjukkan betapa pentingnya legitimasi yang diberikan oleh Kiai Ageng Mohamad Besari dalam konflik tersebut.

Sepeninggal Kiai Ageng Mohamad Besari, kepemimpinan Pesantren Tegalsari dilanjutkan oleh anaknya yaitu Kiai Ilyas (1773-1800). Pada masa kepemimpinan Kiai Ilyas, tradisi mengirimkan calon pujangga untuk belajar di Pesantren Tegalsari dimulai. Sastranagara tercatat sebagai orang pertama yang mengawali tradisi ini. Sastranegara inilah yang kelak setelah diangkat menjadi pujangga namanya berubah menjadi Yasadipura II.11 Pada masa kepemimpinan Kiai Ilyas, tidak banyak yang dapat dikisahkan dari Pesantren Tegalsari selain dimulainya tradisi pengiriman calon pujangga untuk belajar di sana. Hal itu disebabkan oleh

\footnotetext{
${ }^{8}$ Martin van Bruinessen, Contemporary Developments in Indonesian Islam: Explaining the Conservative Turn (Singapore: ISEAS Publishing, 2013), 192.

${ }^{9}$ Periode Perang Jawa dari 1746-1755 dihitung sejak awal konflik sampai Perjanjian Giyanti yang ditandatangani tahun 1755. Lihat: Denys Lombard, Nusa Jawa: Silang Budaya III - Warisan Kerajaan-Kerajaan Konsentris, terj. Winarsih P. Arifin (Jakarta: Gramedia Pustaka Utama, 2005), 46.

${ }^{10}$ Claude Guillot, "Le Rôle Historique Des Perdikan Ou Villages Francs: Le Cas de Tegalsari," Archipel 30 (1985): 142.

${ }^{11}$ Kumite Ranggawarsitan, Serat Babad Cariyos Lelampahanipun Suwargi Raden Ngabei Ranggawarsita (Surakarta: Drikerei Mares, 1931-1933), 1-5.
} 
meredanya konflik politik di Jawa tahun 1773-1800 karena perebutan tahta di Jawa telah selesai.12 Di sisi yang lain, pemerintah kolonial yang seringkali terlibat dalam kompleksitas kontestasi politik keraton juga sedang berada dalam kondisi yang tidak kondusif akibat konflik internal yang melibatkan Belanda, Perancis, dan Inggris.

Tahun 1800 merupakan awal dari melejitnya pamor Pesantren Tegalsari, setelah Kiai Kasan Besari naik menjadi pimpinan pesantren menggantikan Kiai Ilyas. Pada masa kepemimpinan Kiai Kasan Besari (1800-1862), Pesantren Tegalsari menjelma menjadi lembaga pendidikan-keagamaan yang paling terkenal di seantero Jawa. Melejitnya popularitas Pesantren Tegalsari menjadikan Kiai Kasan Besari, sebagai pimpinan pesantren, sebagai sosok yang paling banyak dicari untuk dimintai bantuan, atau sekedar dimintai fatwa atas suatu peristiwa. Dukungan dari seorang kiai penting untuk dimiliki karena dialah orang yang memegang otoritas keagamaan. Oleh karena itu kiai ditempatkan di posisi terhormat, sehingga mampu mempengaruhi dan menggerakkan aksi atau tanggapan emosional para pengikutnya. ${ }^{13}$ Pada titik inilah Kiai Kasan Besari memainkan perannya dengan baik sebagai penggiat harmoni di dalam pranata sosial masyarakat Jawa.

Ada dua peristiwa besar terjadi di Jawa pada masa kepemimpinan Kiai Kasan Besari, yaitu pecahnya Perang Jawa (1825-1830) dan dimulainya sistem tanam paksa (1830-1917). Dalam dua peristiwa ini Kiai Kasan Besari menunjukkan profesionalitasnya sebagai seorang ulama besar yang harus mengayomi semua pihak. Dalam Perang Jawa, Kiai Kasan Besari diminta oleh Sasradilaga, atas nama Pangeran Diponegoro, untuk ikut bertempur di Perang Jawa. Permintaan ini tidak ditolak, tetapi juga tidak diterima secara penuh. Sikap yang ditunjukkan oleh Kiai Kasan Besari adalah sikap ideologis non-praktis. Artinya Kiai Kasan Besari memberikan dukungan untuk melawan dominasi pemerintah kolonial Belanda tidak secara militer, tetapi lebih secara moral. Strategi ini pula yang membebaskan Kiai Kasan Besari dari tuduhan Belanda atas keterlibatannya di Perang Jawa. ${ }^{14}$ Strategi perlawanan yang dilakukan oleh Kiai Kasan Besari

\footnotetext{
12Perang Suksesi Jawa III baru benar-benar selesai tahun 1757 dengan ditandatanginya Perjanjian Salatiga. Perjanjian ini memunculkan Mangkunegaran sebagai daerah otonom setingkat kadipaten, di bawah kepemimpinan Raden Mas Said yang bergelar Adipati Mangkunegara I. Lihat: Pakêmpalan Ngarang Serat ing Mangkunagaran, Serat Babad Panambangan (Surakarta: Indonesise Drikkere, 1918), 173.

13Endang Turmudi, Perselingkuhan Kiai dan Kekuasaan (Yogyakarta: LKiS, 2004), vi.

${ }^{14}$ Guillot, "Le Rôle Historique," 148.
} 
dimaksudkan untuk: 1) menjaga eksistensi Pesantren Tegalsari dan 2) menjaga perekonomian masyarakat Desa Tegalsari yang sedang bergairah dengan produksi dluwang.

Sikap Kiai Kasan Besari untuk ikut menjaga perekonomian masyarakat adalah sebuah bentuk implementasi dari fungsi kiai dalam pranata sosial masyarakat Jawa. Kiai bukan semata-mata pimpinan lembaga pendidikankeagamaan (pesantren), tetapi juga sosok yang harus mampu mengayomi masyarakatnya. Proses pengayoman menjadikan kiai, termasuk segenap warga pesantren, sebagai bagian yang tidak terpisahkan dari masyarakat. Nasaruddin Umar menyebut bahwa kiai dan pesantren memiliki fungsi sebagai social engineering dari pengayomannya terhadap masyarakat, yaitu alat yang ampuh untuk melakukan sebuah rekayasa sosial. ${ }^{15}$

Tulisan ini dimaksudkan sebagai usaha untuk memberikan pemahaman tentang gerakan pemikiran dan sikap ulama Pesantren Tegalsari dalam menghadapi konflik multidimensional di Jawa (1742-1862). Periode 1742-1862 dipilih karena merupakan titik puncak dari sebuah pertarungan sengit antara kekuatan-kekuatan politik yang ada di Jawa, khususnya di tanah Mataram. Di sisi yang lain, periode 1742-1862 adalah masa keemasan dari Pesantren Tegalsari, yang tidak pernah dicapai lagi pada masa sesudahnya.

Beberapa studi yang sudah dilakukan terkait dengan Pesantren Tegalsari antara lain berjudul "The Dynamics of Tegalsari (Santri and Descendants of Pesantren Tegalsari Ponorogo Kiai's in 19-20 th $)$ oleh Dawam Multazam yang dimuat dalam jurnal Qalamuna 9, no. 1 (2017). Dalam studinya Dawam menunjukkan bahwa Pesantren Tegalsari didirikan oleh Kiai Ageng Mohamad Besari yang berasal dari keturunan Brawijaya V dan Sunan Ampel. Darah dari dua tokoh besar tanah Jawa yang mengalir dalam diri Kiai Ageng Mohamad Besari dan keturunan-keturunannya menyebabkan pesantren yang mereka pimpin, secara sosiologis, mendapatkan legitimasi yang kuat dari masyarakat. Beberapa pesantren yang didirikan oleh keturunan dari Kiai Ageng Mohamad Besari antara lain Pondok Modern Darussalam Gontor, Pesantren Coper, Pesantren Darul Hikam Joresan, dan Pesantren Darul Huda Mayak.16 125.

${ }^{15}$ Nasaruddin Umar, Rethinking Pesantren (Jakarta: Elex Media Komputindo (Quanta), 2014),

16Dawam Multazam, "The Dynamics of Tegalsari (Santri and Descendants of Pesantren Tegalsari Ponorogo Kiai's in 19-20th)," Qalamuna 9, no. 1 (2017): 91-110. 
Kedua, "Local Muslim Heritage: Pelestarian Warisan Budaya Pesantren di Tegalsari Ponorogo" oleh Dawam Multazam yang dimuat dalam Prosiding Second Annual Conference For Muslim Scholars dengan tema "Strengthening The Moderate Vision of Indonesian Islam" tanggal 21-22 April 2018. Dalam tulisan ini Dawam memaparkan warisan budaya yang dilakukan oleh masyarakat Desa Tegalsari yang diklaim berasal dari masa Kiai Ageng Mohamad Besari. Warisan budaya tersebut adalah manuskrip kitab kuning yang berjumlah 69 buah, ritual syiíran yang terdiri dari tiga jenis yaitu ujud-ujudan, utawen, dan shallallahu. Ujud-ujudan adalah syair yang disenandungkan dengan topik utama sifat Allah berupa wujud sementara utawen dengan topik utama rukun Islam. Adapun shallallahu adalah shalawat yang dibaca bersama-sama dengan penekanan pada bunyi $h u^{\prime} .^{17}$

Ketiga, "Le Rôle Historique Des Perdikan Ou Villages Francs: Le Cas de Tegalsari" oleh Claude Guillot yang dimuat dalam jurnal Archipel, Vol. 30, tahun 1985. Dalam tulisannya, Guillot menjelaskan bahwa status tanah perdikan diberikan oleh Pakubuwana II setelah Kiai Ageng Mohamad Besari membantunya secara spiritual dalam menyelesaikan peristiwa geger pacina tahun 1742. Dalam perkembangannya, status tanah perdikan juga diberikan di beberapa desa yang lain tetapi tetap di bawah kontrol dari pimpinan desa perdikan Tegalsari, sehingga Desa Tegalsari menjadi semacam primus inter pares di antara desa-desa perdikan yang lain.

Perbedaan penelitian ini dengan penelitian yang sudah dilakukan sebelumnya terletak pada pokok bahasan. Dalam penelitian ini, pokok bahasan yang akan ditonjolkan adalah tentang posisi Pesantren Tegalsari dilihat dari sudut pandang politik. Secara lebih lanjut akan dibahas mengenai pemikiran dan sikap tiga pimpinan pertama Pesantren Tegalsari dalam menghadapi konflik multidimensional di Jawa tahun 1742-1862.

Metode yang digunakan dalam penelitian ini adalah metode historis dengan menggunakan pendekatan politik-poskolonial. Pendekatan poskolonial digunakan karena sumber primer dari penelitian menggunakan catatan-catatan kolonial, yang ditulis dari perspektif kaum kolonial. Maka pendekatan pos-

\footnotetext{
${ }^{17}$ Dawam M. Rohmatulloh, "Local Muslim Heritage: Pelestarian Warisan Budaya Pesantren Di Tegalsari Ponorogo," Proceedings Second Annual Conference For Muslim Scholars "Strengthening The Moderate Vision of Indonesian Islam, April (2018): 232-39.
} 
kolonial digunakan dalam mengkaji gerakan pemikiran dan sikap ulama Pesantren Tegalsari dalam menghadapi konflik multidimensional di Jawa (17421862), dengan mengungkapkan perspektif kaum terjajah (bangsa Indonesia) yang telah teralienasi oleh historiografi elitis kolonial.

\section{B. Pesantren Tegalsari}

Pesantren Tegalsari adalah salah satu pesantren tertua di Indonesia yang didirikan oleh Kiai Ageng Mohamad Besari pada paruh pertama abad delapan belas. ${ }^{18}$ Nama asli dari pesantren ini adalah Pesantren Gebang Tinatar. Gebang memiliki arti pintu gerbang dan tinatar berarti tempat pijakan. Secara harfiah gebang tinatar dapat diartikan sebagai gerbang yang dituju melalui tempat pijakan. Secara filosofis dapat dimaknai bahwa Pesantren Gebang Tinatar adalah tempat untuk mengolah kekuatan spiritual untuk mencapai pintu gerbang keabadian, yaitu surga yang dijanjikan oleh Allah bagi orang yang beriman dan beramal saleh.19 Dalam perjalanannya, nama Tegalsari lebih dikenal oleh masyarakat merujuk kepada letak geografis pesantren tersebut yaitu di Desa Tegalsari.

Pilihan untuk mendirikan pesantren di Desa Tegalsari muncul karena ajakan dari guru Kiai Ageng Mohamad Besari yaitu Kiai Donopuro yang tinggal di Desa Setono. ${ }^{20}$ Tidak ada penjelasan lebih lanjut mengenai pertimbangan pemilihan Desa Tegalsari. Pertimbangan geografis menjadi kemungkinan yang paling masuk akal, yaitu letak dari Desa Tegalsari yang berada di sekitar daerah aliran Sungai Keyang. Seperti umumya, sebuah pemukiman baru selalu terletak di dekat aliran sungai untuk menunjang kebutuhan sehari-hari warganya.

Martin van Bruinessen, seorang Indonesianis berkebangsaan Belanda yang telah lama meneliti sejarah Islam Nusantara, berpendapat bahwa Pesantren Tegalsari adalah pesantren pertama yang berdiri di Jawa. ${ }^{21}$ Pendapat dari

\footnotetext{
18Tidak ada catatan resmi tentang kapan berdirinya Pesantren Tegalsari. Catatan tertua yang ditemukan adalah Pesantren Tegalsari sudah berdiri dan masyhur pada tahun 1742, sehingga menjadi tujuan pengungsian Pakubuwana II ketika terjadi geger pacina di Kartasura. Lihat: F. Fokkens, "De Priesterschool te Tegalsari," Tijdschrift Voor Indische Taal-, Land- En Volkenkunde, Deel 24 (1877), 319.

${ }^{19}$ Setyo Wacono (keturunan ke-7 Kiai Ageng Mohamad Besari), wawancara, Rabu 7/2/2018.

${ }^{20}$ Guillot, "Le Rôle Historique," 139.

${ }^{21}$ Martin Van Bruinessen, Kitab Kuning, Pesantren, dan Tarekat: Tradisi-tradisi Islam di Indonesia (Bandung: Mizan, 1995), 25
} 
Bruinessen ini bisa saja benar apabila pesantren yang dimaksud merujuk kepada teori dari Zamakhsyari Dhofier tentang lima elemen pokok yang harus dipenuhi oleh institusi pesantren, yaitu adanya pondok, masjid, santri, pengajaran kitab kuning, dan kiai. ${ }^{22}$ Tetapi apabila pesantren yang dimaksud adalah sebuah tempat berkumpul untuk belajar agama, tanpa adanya sistematisasi proses pembelajaran, maka pendapat yang menyatakan Tegalsari sebagai pesantren tertua tidak bisa dijadikan landasan, karena ada lembaga pendidikan serupa yang jauh lebih tua yaitu Pesantren Jan Tampes II di Pamekasan, Madura. ${ }^{23}$

Terlepas dari perdebatan di atas, tidak dapat dipungkiri bahwa Pesantren Tegalsari adalah embrio dari lembaga pendidikan pesantren yang berdiri pada masa setelahnya. Pesantren Tegalsari tampil sebagai pelopor dari upaya sistematisasi institusi pesantren. Pembelajaran di pesantren yang sebelumnya dilakukan secara sederhana dan pada waktu-waktu tertentu, biasanya setelah shalat Ashar dan Magrib, maka di Pesantren Tegalsari inilah dimulai untuk melakukan proses pembelajaran sepanjang hari dengan kitab-kitab beragam, mirip seperti pesantren yang ada pada saat ini. Catatan dari Fokkens yang dimuat tahun 1877 menjelaskan, di Pesantren Tegalsari sudah ada klasifikasi pembelajaran antara murid yang baru belajar dengan murid yang sudah memiliki pengetahuan lanjut. Bagi murid yang baru belajar, mereka diajarkan tentang baca-tulis dalam bahasa Arab. Sedangkan bagi yang sudah mampu bacatulis arab, mereka diajarkan untuk membaca dan menjelaskan kitab-kitab agama dalam bahasa Arab (kitab kuning). Proses pembelajaran dilakukan secara wetonan dari pukul 07.00-16.00 dan sorogan ketika malam hari, biasanya setelah sholat isya sekitar pukul 19.30-21.00.24

22 Multazam, “The Dynamics of Tegalsari,” 92.

${ }^{23}$ Departemen Agama RI mencatat Pesantren Jan Tampes II didirikan pada tahun 1062. Tetapi catatan inipun masih diperdebatkan, karena kalau ada Jan Tampes II berarti seharusnya ada pula Jan Tampes I. Dindin Solahudin, The Workshop for Morality: The Islamic Creativity of Pesantren Daarut Tauhid in Bandung Java (Canberra: ANU E Press, 2008), 4.

${ }^{24}$ Fokkens, "De Priesterschool te Tegalsari," 335; Wetonan dan sorogan memiliki definisi yang sama, yaitu metode belajar yang berpusat pada individu, yakni seorang atau beberapa orang santri duduk di depan kiai dan membaca kitab-kitab keagamaan. Perbedaannya adalah, sorogan dilakukan berdasarkan permintaan dari santri kepada kiainya, sementara wetonan dilakukan berdasarkan inisiatif dari kiai. Lihat: Nurcholis Majid, Bilik-bilik Pesantren: Sebuah Potret Perjalanan Uakarta: Paramadina, 1997), 28. 


\section{Kondisi Sosial-Ekonomi Masyarakat Desa Tegalsari}

Dilihat dari topografinya, wilayah Desa Tegalsari dikategorikan sebagai daerah datar dan landai. Sebelum dibuka oleh Kiai Ageng Mohamad Besari, sesuai dengan namanya, wilayah Desa Tegalsari merupakan tanah tegal. ${ }^{25}$ Dalam perjalanannya, tanah tegal ini secara bertahap berubah fungsi menjadi tanah pertanian.

Sebagian besar masyarakat Desa Tegalsari pada abad ke-18-19 bermata pencaharian sebagai petani, sebagaimana layaknya kehidupan masyarakat Jawa pada umumnya. Komoditas pertanian yang paling banyak ditanam adalah padi dan kedelai. Kegiatan perekonomian mulai berkembang ke sektor lain seiring dengan perkembangan Pesantren Tegalsari. Kegiatan literasi yang dilakukan di Pesantren Tegalsari menyebabkan masyarakat sekitar berusaha memenuhi kebutuhan tersebut. Salah satu yang paling dibutuhkan dalam kegiatan literasi adalah kertas, sehingga masyarakat berusaha memproduksi kertas guna menunjang aktifitas literasi di pesantren.

Abad ke-18, kertas dari Cina yang berbahan dasar bambu sudah dikenal oleh masyarakat Jawa. Tetapi entah karena alasan apa, kertas dari Cina ini kurang diminati oleh masyarakat Jawa. Masyarakat Jawa lebih menyukai penggunaan dluwang yang berbahan dasar kulit pohon kelapa (glugu) sebagai media untuk menulis. Oleh karena itu dluwang sering disebut oleh kaum kolonial dengan istilah Javanese paper.26 Dluwang, dalam perkembangannya, tidak hanya digunakan untuk kebutuhan pesantren, tetapi juga dijual ke daerah lain. Oleh sebab itu, masyarakat Tegalsari kemudian memproduksi dluwang dalam jumlah besar. Dari perdagangan dluwang inilah masyarakat Desa Tegalsari menggantungkan hidupnya di samping dari sektor pertanian.

Memasuki abad ke-19, produksi dluwang di Jawa mengalami penurunan yang signifikan karena masyarakat beralih ke kertas buatan Eropa dengan kualitas yang lebih baik. ${ }^{27}$ Pada abad ke-19, Tegalsari menjadi salah satu dari

\footnotetext{
${ }^{25}$ Tanah tegal adalah daerah lahan kering yang bergantung pada pengairan air hujan dan ditanami tanaman non-musiman (palawija). Peter H. Lindert, Shifting Ground: The Changing Agricultur Soils of China and Indonesia (London: The MIT Press, 2000), 166.

26R. Teygeler, "Dluwang, a Near-Paper from Indonesia," dalam IPH Congress Book 1996, vol. 11 (Marburg: International Association of Paperhistorians, 1996), 134-45.

${ }^{27}$ Penurunan produksi dluwang sebenarnya sudah mulai mengalami penuruan sejak abad ke17, tetapi baru benar-benar anjlok di awal abad ke-19. Lihat: Lombard, Nusa Jawa: Silang Budaya III, 179.
} 
sedikit daerah yang masih memproduksi dluwang. Oleh karena itu, pada abad ke-19 dluwang juga sering disebut dengan istilah Ponorogo paper. ${ }^{28}$ Kegiatan perekonomian masyarakat Tegalsari yang dinamis menjadikan desa ini menjadi salah satu daerah paling ramai di kota Ponorogo. Fokkens mencatat, di akhir abad ke-19 jumlah penduduk Desa Tegalsari mencapai 1.679 jiwa, jumlah yang cukup besar untuk ukuran desa di abad ke-19.29

Berkaitan dengan hubungan antara agama dan semangat kapitalisme atau etos kerja, Max Weber menyatakan di dalam tesisnya bahwa semangat capitalisme komunitas Islam tidak bisa tumbuh akibat kultur patrimonialisme di dalam tubuh Islam. ${ }^{30}$ Dalam kasus masyarakat Tegalsari di atas, tampaknya tesis dari Weber tidak relevan dengan fakta yang ada. Kasus di Tegalsari menunjukkan bahwa kultur patrimonialisme yang menempatkan kiai sebagai patron dan masyarakat sebagai client ternyata justru dapat meningkatkan semangat kapitalisme masyarakat Tegalsari dengan produksi dluwang. Kasus di Tegalsari pada abad 18-19 juga membantah pernyataan Weber bahwa agama Islam, Katolik, dan Budha adalah agama-agama yang tidak mendukung proses produksi, sebagai prasyarat munculnya kapitalisme awal, karena ketiganya dianggap agama yang menyebarkan paham asketik dan hidup membiara, serta agama prajurit, bukan agama kapital. ${ }^{31}$

\section{Pesantren Tegalsari dan Gejolak Konflik Multidimensional di Jawa tahun 1742-1830}

Antara abad ke-18 dan abad ke-19 adalah masa-masa ketika tanah Jawa penuh dengan gejolak, baik sosial maupun politik. Gejolak pertama terjadi pada tahun 1742 ketika pecah peristiwa geger pacina di Kartasura. Peristiwa ini diawali dari kekecewaan masyarakat etnis Cina dan Jawa terhadap inkonsistensi sikap Pakubuwana II. Pakubuwana II yang semula mendukung perlawanan etnis Cina terhadap VOC tiba-tiba mengubah keputusannya dengan memusuhi

${ }^{28}$ Claude Guillot, “Le Dluwang ou: Papier Javanais,” Archipel 26 (1983): 105.

${ }^{29}$ Fokkens, "De Priesterschool te Tegalsari," 325.

${ }^{30}$ Radjasa Mu'tasim, Timbul Haryono, dan St. Sunardi, Agama dan Pariwisata (Yogyakarta: Pustaka Pelajar, 2013), 4.

${ }^{31}$ Muhammad Djakfar, Etika Bisnis: Menangkap Spirit Ajaran Langit dan Pesan Moral Ajaran Bumi (Jakarta: Penebar Plus+, 2012), 91. 
etnis Cina dan menghukum pasukan-pasukan yang telah dikirim ke Semarang sebelumnya. ${ }^{32}$

Perubahan sikap politik secara mendadak menyebabkan Pakubuwono II mengalami krisis kepercayaan. Pasukan anti VOC, baik dari etnis Cina maupun etnis Jawa, sama-sama kecewa dengan inkonsistensi sang Raja. Pasukan dari kedua etnis itu kemudian berkolaborasi untuk meluapkan kekecewaan mereka terhadap Pakubuwono II dengan menyerang Keraton Kartasura. Upaya pemberontakan berhasil merebut keraton Kartasura dan memaksa Pakubuwono II mengungsi ke Pesantren Tegalsari di Ponorogo. ${ }^{33}$

Keputusan Pakubuwana II untuk melarikan diri ke Pesantren Tegalsari didasari atas pertimbangan bahwa pesantren yang terletak di Ponorogo ini dianggap tidak terlibat dengan pemberontakan di Kartasura. Peta pemberontakan yang terjadi di Kartasura menunjukkan bahwa para pemberontak bukan berasal dari gabungan kaum aristorat dengan pesantren seperti kasus pemberontakan Trunojoyo terhadap Amangkurat I di akhir abad ke-17, melainkan berasal dari gabungan kekuatan rakyat (Jawa, Cina) dengan kekuatan aristokrat yang berseberangan dengan Pakubuwana II (P. Mangkubumi, RM. Said). ${ }^{34}$ Fakta inilah yang kemudian memantapkan Pakubuwana II untuk berlindung di Pesantren Tegalsari.

Pasca terjadinya geger pacina, suhu politik di Jawa tampaknya masih memanas. Pakubuwono II yang wafat pada tahun 1749 ternyata meninggalkan konflik internal antara Pangeran Mangkubumi, Raden Mas Said, dan Pakubuwana II sendiri.35 Pangeran Mangkubumi dan Raden Mas Said yang sebelumnya mendukung peristiwa geger pacina tahun 1742, masih menyimpan keinginan untuk memiliki kekuasaan tersendiri yang terpisah dari Kasunanan Surakarta. Episode ini disebut oleh para sejarawan sebagai Perang Suksesi Jawa III.

32Djakfar, Etika Bisnis, 205-206.

${ }^{33}$ R. Sasrasumarta, dkk., Tus Pajang (Surakarta: Budi Utama, 1939), 14.

${ }^{34}$ Nancy K. Florida, Javanese Literature in Surakarta Manuscripts Vol. II: Manuscripts of The Mangkunagaran Palace (Itacha: Cornell University Press, 2000), 138.

35Pakubuwana II dan Pangeran Mangkubumi adalah anak dari Amangkurat IV, sementara Raden Mas Said adalah anak dari Arya Mangkunegara. Arya Mangkunegara sendiri juga salah satu anak dari Amangkurat IV. Jadi hubungan antara Pakubuwana II, Pangeran Mangkubumi, dan Raden Mas Said adalah hubungan antara paman dan keponakan. Lihat: Willem G.J. Remmelink, Perang Cina dan Runtuhnya Negara Jawa, 1725-1743, terj. Akhmad Santoso (Yogyakarta: Jendela, 2002), 335-40. 
Dalam Perang Suksesi Jawa III, Pesantren Tegalsari tidak mau terlalu ikut campur dalam konflik internal ini. Tetapi bagaimanapun juga konsep jejer pandhita yang menjadi worldview para bangsawan Jawa menyebabkan pesantren selalu dilibatkan dalam kontestasi kekuasaan. Pangeran Mangkubumi adalah orang yang tercatat mendatangi Kiai Ageng Mohamad Besari di Tegalsari untuk meminta dukungan moral dan spiritual dalam rangka memenangkan Perang Suksesi Jawa III.

Kedatangan Pangeran Mangkubumi ke Pesantren Tegalsari menjadi satu hal yang menarik karena Kiai Ageng Mohamad Besari adalah orang yang melindungi Pakubuwana II ketika terjadi geger pacina tahun 1742. Artinya secara tersirat dapat dilihat bahwa Kiai Ageng Mohamad Besari adalah orang yang berada di pihak Pakubuwana II, atau paling tidak Kiai Ageng Mohamad Besari bukanlah musuh dari Pakubuwana II. Hasil dari pertemuan inipun sudah dapat ditebak, yaitu penolakan Kiai Ageng Mohamad Besari untuk terlibat lebih jauh dalam konflik internal tersebut. ${ }^{36}$ Perang Suksesi Jawa III sendiri berakhir dengan pembagian kekuasaan kepada pihak-pihak yang terlibat konflik, Pangeran Mangkubumi mendapatkan jatah Kasultanan Yogyakarta, RM. Said mendapatkan Kadipaten Mangkunegaran, dan Pakubuwana III sebagai Raja Kasunanan Surakarta dengan wilayah yang jauh lebih sedikit dari sebelumnya.

Pasca Perang Suksesi Jawa III yang terjadi hampir lima belas tahun, keadaan politik di Jawa relatif lebih stabil. Konflik dalam skala besar baru muncul pada tahun 1825, ketika pecah Perang Jawa. Perang Jawa yang berlangsung antara tahun 1825-1830 menjadi salah satu perang terbesar yang pernah dihadapi oleh Belanda selama penjajahannya di Indonesia. Inilah pertama kalinya pemerintah kolonial Belanda menghadapi perlawanan sosial yang berkobar di sebagian besar pulau Jawa.

Pada masa Perang Jawa, Pesantren Tegalsari kembali menjadi institusi yang berusaha dilibatkan dalam pusaran konflik. Sasradilaga adalah orang yang datang ke Pesantren Tegalsari dengan membawa nama Pangeran Diponegoro untuk meminta bantuan kepada Kiai Kasan Besari agar mau terlibat dalam Perang Jawa. ${ }^{37}$ Satu hal yang menjadi perbedaan adalah, apabila pada masa

\footnotetext{
${ }^{36}$ Guillot, "Le Rôle Historique," 142.

${ }^{37}$ Sasradilaga adalah mantan Bupati Rajegwesi yang menjadi salah satu pimpinan Perang Jawa di Jawa Timur. Lihat Guillot, "Le Rôle Historique," 148.
} 
konflik internal keraton Pesantren Tegalsari dilibatkan sebagai upaya untuk mencari legitimasi moral-spiritual, maka dalam Perang Jawa Pesantren Tegalsari dilibatkan dengan harapan agara warga pesantren ikut berperang secara fisik, karena perang ini dikobarkan atas dasar semangat keagamaan (perang sabil) untuk melawan orang-orang kafir di tanah Jawa. ${ }^{38}$

\section{E. Pemikiran dan Sikap Politik Kiai Ageng Mohamad Besari (1742- 1773)}

Kiai Ageng Mohamad Besari adalah orang yang membuka pemukiman di daerah Tegalsari, sekaligus pendiri dari Pesantren Tegalsari. Sebutan "kiai ageng" sendiri merujuk kepada tradisi masyarakat Jawa untuk menyebut seseorang dengan kualitas kedekatan kepada Allah, serta menjadi pengageng atau pembesar/pemimpin di bidang keagamaan yang mengarah pada kehidupan spiritual. ${ }^{39}$ Kiai Ageng Mohamad Besari memimpin Pesantren Tegalsari selama kurang lebih 31 tahun, terhitung dari 1742-1773.40 Pada masa kepemimpinannya, Kiai Ageng Mohamad Besari menjadi saksi atas dua peristiwa besar yang terjadi di tanah Jawa, yaitu geger pacina (1742) dan Perang Suksesi Jawa III (1746-1755).

Ketika terjadi geger pacina, Pakubuwana II yang saat itu menjabat sebagai Raja Mataram terpaksa mengungsi akibat didudukinya Keraton Kartasura oleh para pemberontak. Pesantren Tegalsari kemudian dipilih untuk dijadikan tempat pengungsian. Pilihan untuk menjadikan Pesantren Tegalsari sebagai tempat pengungsian tidak lepas dari konsep jejer pandhita yang dijadikan pegangan oleh raja-raja Jawa, termasuk Pakubuwana II. Kiai Ageng Mohamad Besari memang dikenal oleh masyarakat Ponorogo sebagai sosok yang memiliki kelebihan di bidang spiritual. Oleh karena itu, Pakubuwana II ingin menampilkan sosok Kiai Ageng Mohamad Besari sebagai seorang pandhita yang akan membimbingnya dalam setiap tindakan yang akan diambil. Pada titik inilah

\footnotetext{
38Peter Carey, Takdir: Riwayat Pangeran Diponegoro 1785-1855 (Jakarta: Kompas, 2017), 318.

${ }^{39}$ Muhammad Widda Djuhan, "Ritual di Makam Ki Ageng Besari Tegalsari Jetis Ponorogo," Kodifikasia 5, no. 1 (2011): 177.

${ }^{40}$ Hitungan ini merujuk kepada kedatangan Pakubuwana II yang mengungsi ke Pesantren Tegalsari tahun 1742. Jumlah sebenarnya kemungkinan besar lebih dari itu, karena Pesantren Tegalsari telah eksis ketika Pakubuwana II datang. Lihat: Guillot, "Le Rôle Historique Des Perdikan Ou Villages Francs: Le Cas de Tegalsari, " 139.
} 
posisi Kiai Ageng Mohamad Besari sebagai seorang ideolog dikukuhkan, dan Pakubuwana II menjadi eksekutor dari konsep-konsep sang Kiai.

Alasan kedua dari pemilihan Pesantren Tegalsari sebagai tempat pengungsian tidak terlepas dari darah bangsawan yang dimiliki oleh kiai-kiai besar di Jawa. Pilihan raja untuk mencari suaka kepada seorang kiai dianggap lebih bermartabat dibandingkan di tempat lain, karena antara raja dan kiai sama-sama berasal dari trahing kusumo rembesing madu, urijining atopo, tedhaking andono warih (keturunan bunga bangsa, tetesan madu, berbenih petapa, keturunan bangsawan). Kiai Ageng Mohamad Besari, dilihat dari silsilahnya, memiliki leluhur yang sama dengan Pakubuwana II yaitu Prabu Brawijaya V dari Majapahit.41

Selain kedua pertimbangan di atas, pilihan Pakubuwana II untuk mengungsi ke Tegalsari juga disebabkan karena pesantren ini dianggap tidak memiliki keterlibatan dalam konflik di Kartasura. Konflik di Kartasura sendiri didominasi oleh kaum aristokrat yang mencoba menggulingkan kekuasaan Pakubuwana II.42 Tidak ada bukti yang mengarahkan bahwa pemberontakan di Kartasura didukung oleh kaum pesantren, seperti ketika Trunojoyo beraliansi dengan Pesantren Tembayat untuk menggulingkan Amangkurat I. Pesantren Tegalsari juga tidak memiliki riwayat konflik politik yang seringkali menjadikan pesantren terisolasi dari kehidupan keraton. ${ }^{43}$ Singkat kata Pesantren Tegalsari, dari sisi historis, menjadi pilihan tempat pengungsian karena netralitasnya dalam menyikapi sebuah politik.

Kedatangan Pakubuwana II ke Pesantren Tegalsari menyebabkan naiknya posisi tawar pesantren dalam konstelasi politik Jawa abad-18. Keadaan ini diperkuat dengan keberhasilan Kiai Ageng Mohamad Besari dalam membantu Pakubuwana II secara spiritual untuk mengakhiri konflik di Kartasura. Berkat keberhasilan ini pula Pakubuwana II kemudian memberikan status tanah

\footnotetext{
${ }^{41}$ Silsilah Kyai \& Nyai Ageng Anom Besari (Madiun, t.th.).

${ }^{42}$ Beberapa tokoh penting yang terlibat pemberontakan ini adalah Pangeran Mangkubumi, Pangeran Singasari, dan Raden Mas Said. Lihat: Merle Calvin Ricklefs, Sejarah Indonesia Modern 1200-2008 (Jakarta: Serambi Ilmu Semesta, 2008), 208.

43Pesantren merupakan basis massa yang sangat kuat sehingga sangat potensial dijadikan sebagai basis pemberontakan. Hal inilah yang terjadi di Pesantren Tembayat dan Kajoran yang memiliki riwayat konflik pada masa pemerintahan Amangkurat I di akhir abad ke-17. Lihat: Anthony Reid, Asia Tenggara dalam Kurun Niaga 1450 - 1680 Jilid 2: Jaringan Perdagangan Global (Jakarta: Yayasan Pustaka Obor Indonesia, 2011), 372.
} 
perdikan (tanah bebas pajak) kepada Desa Tegalsari. ${ }^{44}$ Selain itu, Kiai Ageng Mohamad Besari, sesuai dengan piagam bertanggal 9 April 1746 dari Sunan Pakubuwana II, juga diberikan kekuasaan Reh Kapangulon, yaitu hakim dari pengadilan Surambi yang menangani masalah persengketaan keluarga, warisan, pernikahan, perceraian, harta gana-gini, dan memutuskan segala perkara dari pengadilan Pradata. 45

Naiknya daya tawar yang dimiliki oleh Pesantren Tegalsari dipahami betul oleh Kiai Ageng Mohamad Besari. Keadaan itu sebenarnya juga membuka peluang Kiai Ageng Mohamad Besari untuk masuk dan ikut dalam kontestasi politik keraton. Tetapi sepertinya pilihan tersebut tidak menarik bagi sang Kiai yang lebih memilih untuk tetap menjalankan aktifitasnya sebagai pendidik di Pesantren Tegalsari, sembari melaksanakan tugasnya sebagai Reh Kapangulon. Pilihan itu diambil dengan dua alasan: 1) instabilitas politik Mataram dan 2) memastikan agar kehidupan sosial-ekonomi masyarakat Tegalsari tetap lestari.

Kiai Ageng Mohamad Besari memahami bagaimana perpolitikan Mataram sedang bergejolak, dimana kelompok-kelompok yang sedang bertarung (Pakubuwana II, Mangkubumi, dan Mas Said) memiliki kekuatan yang hampir sama. Masuknya Kiai Ageng Mohamad Besari dalam arus kontestasi kekuasaan dengan masuk sebagai bagian dari salah satu kelompok hanya akan memperkeruh suasana, merusak reputasi dirinya dan Pesantren Tegalsari yang dia pimpin. Rusaknya reputasi ini tentu akan berdampak buruk terhadap kehidupan sosial-ekonomi masyarakat Tegalsari yang ketika itu dikenal sebagai penghasil dluwang kualitas tinggi. Pada posisi inilah Kiai Ageng Mohamad Besari memainkan peran sebagai penjaga harmoni di dalam masyarakat.

Menurut Daverger, peran kiai sebagai penjaga harmoni di dalam masyarakat adalah konsekuensi logis dari hakikat kiai itu sendiri. Seorang kiai, selain sebagai individu, pada hakikatnya dia adalah sebuah institusi dengan pengaruh yang kuat terhadap fenomena sosial-ekonomi dan sosial-politik yang berada di luarnya. Lebih lanjut Daverger mendefinisikan institusi sebagai model hubungan antar individu dengan pola tertentu, dimana dengan pola itu tumbuh

\footnotetext{
${ }^{44}$ Hadi Kusnanto dan Yudi Hartono, "Masjid Tegalsari Jetis Ponorogo (Makna Simbolik Dan Potensinya sebagai Sumber Pembelajaran Sejarah Lokal)," Gulawentah: Jurnal Studi Sosial 2, no. 1 (2017): 43.

${ }^{45}$ Katno, "Penerapan Hukum Islam di Keraton Kasunanan Surakarta Masa Pakoe Boewono IV (Tahun 1788-1820 M)," Profetika: Jurnal Studi Islam 16, no. 1 (2015): 53.
} 
stabilitas, kelangsungan, dan kekohesifan. ${ }^{46}$ Konsep ini diperankan dengan baik oleh Kiai Ageng Mohamad Besari dalam mengayomi masyarakat Desa Tegalsari.

Dampak positif dari gerakan pemikiran dan sikap Kiai Ageng Mohamad Besari adalah eksistensi pesantren dan menguatnya kohesivitas sosial masyarakat Desa Tegalsari. Kedua elemen, warga pesantren dan masyarakat Desa Tegalsari, dapat tetap lestari tanpa harus terombang-ambing oleh politik kerajaan. Sikap Kiai Ageng Mohamad Besari ini kelak akan dilanjutkan oleh kiaikiai penerusnya dalam menyikapi konflik yang sering terjadi.

\section{F. Kiai Ilyas: Masa Damai dan Awal Mula Pesantren Tegalsari sebagai Lembaga Pencetak Pujangga (1773-1800)}

Posisi Kiai Ageng Mohamad Besari sebagai pimpinan Pesantren Tegalsari digantikan oleh anaknya yaitu Kiai Ilyas. Kiai Ilyas memimpin pesantren selama 27 tahun, terhitung sejak tahun 1773-1800. Pada masa kepemimpinan Kiai Ilyas, keadaan Pesantren Tegalsari relatif lebih stabil dibandingkan pada masa sebelumnya. Stabilitas ini disebabkan oleh beberapa faktor. Salah satu faktor yang paling berpengaruh adalah meredanya gejolak politik di Jawa, setelah semua pihak yang berkonflik (Pakubuwana III, Mangkubumi atau Hamengkubuwana I, dan Mas Said atau Mangkunegara I) mendapatkan jatah kekuasaannya masing-masing. Selain itu, status tanah perdikan yang disandang oleh Desa Tegalsari menyebabkan VOC tidak bisa ikut campur secara langsung dalam urusan internal pesantren. Lagipula, tidak ada alasan bagi VOC untuk mengusik keberadaan Pesantren Tegalsari karena tidak ada riwayat dari pesantren ini dalam konflik yang mengganggu eksistensi dari VOC.

Stabilitas politik pada tahun-tahun kepemimpinan Kiai Ilyas di Pesantren Tegalsari memberikan dampak positif pada aktifitas akademik di pesantren. Kiai Ilyas juga dapat lebih fokus untuk meningkatkan kualitas keilmuan di pesantren yang dia pimpin tanpa perlu disibukkan oleh konflik, khususnya konflik perebutan kekuasaan seperti pada masa sebelumnya. Memodifikasi dari teori developmentalisme Rostow, salah satu prasyarat pembangunan adalah stabilitas politik, dimana stabilitas tersebut diciptakan guna kepentingan pembangun-

${ }^{46}$ Ali Maschan Moesa, Nasionalisme Kiai: Konstruksi Sosial Berbasis Agama (Yogyakarta: LKiS, 2007), 62. 
an. ${ }^{47}$ Dalam kasus Kiai Ilyas di Tegalsari ini stabilitas politik tidak dia ciptakan, karena memang tidak memiliki kuasa untuk menciptakan itu, tetapi dengan cerdik Kiai Ilyas memanfaatkan stabilitas politik kerajaan untuk melakukan pembangunan di Pesantren Tegalsari, khususnya dalam membangun tradisi intelektual pesantren.

Tradisi intelektual yang dikembangkan oleh Kiai Ilyas menyebabkan banyak santri berdatangan ke Pesantren Tegalsari, termasuk dari para pujangga senior yang ingin mendidik anak-anaknya dalam ilmu agama. Yasadipura I adalah pujangga pertama yang mengirimkan anaknya, Sastranegara, untuk belajar di Pesantren Tegalsari. Pengiriman ini adalah upaya kaderisasi Yasadipura I agar Sastranagara dapat menggantikan dirinya sebagai pujangga keraton di masa yang akan datang. ${ }^{48}$ Kedatangan Sastranagara untuk belajar di Pesantren Tegalsari menjadi embrio dari tradisi pengiriman para calon pujangga Kasunanan Surakarta untuk belajar dan menempa diri di Pesantren Tegalsari. Puncaknya adalah ketika Bagus Burhan, yang kelak bergelar Ranggawarsita, dikirimkan oleh Yasadipura II untuk belajar ke Pesantren Tegalsari pada tahun $1814 . .^{49}$

Pengiriman calon pujangga ke Pesantren Tegalsari menunjukkan bahwa pesantren ini memang menjadi pusat kegiatan intelektual di Jawa pada abad ke18. Satu hal yang menjadi catatan di sini adalah, Kiai Ilyas tidak membangun dan tidak pula mengembangkan tradisi sastra di Pesantren Tegalsari. Kiai Ilyas hanya membangun dan mengembangkan tradisi keilmuan yang sudah ada sebelumnya di pesantren. Ilmu-ilmu tersebut dapat berkembang dengan baik sebagai dampak dari stabilitas politik Jawa pada masa kepemimpinan Kiai Ilyas di Pesantren Tegalsari.

Maka jika ditelusuri lebih lanjut, tradisi pengiriman calon pujangga ke Pesantren Tegalsari tidak ada kaitannya dengan tradisi sastra yang dikembangkan di pesantren ini, tetapi berhubungan dengan syarat-syarat yang harus dipenuhi oleh orang yang ingin menjadi pujangga. Dalam Serat Wirid Hidayat

\footnotetext{
47Setiawan Djody, Reformasi dan Elemen-elemen Revolusi (Jakarta: 2009), 105.

${ }^{48}$ Kelak setelah menjadi pujangga Sastranagara mendapatkan gelar sebagai Yasadipura II Kumite Ranggawarsitan, Serat Babad.

${ }^{49}$ Fida Indra Fauziyyah, Warto, and Sariyatun, "Ronggowarsito's Concept of Islamic Theosophy in Serat Sabdajati," International Journal of Multicultural and Multireligious Understanding 5, no. 2 (2018): 178, http://ijme-journal.org/index.php/ijme/pages/view/SpecialIssue2017.
} 
Jati dijelaskan delapan syarat untuk menjadi seorang pujangga yaitu: ngawirya (orang yang luhur dan punya derajat), ngagama (menguasai ilmu agama), ngatapa (petapa yang ahli riyalat), sujana (orang yang memiliki kelebihan), ngaguna (orang yang memiliki kepandaian), prawira (prajurit yang tersohor), supunya (orang yang berharta), dan supatya (petani yang tekun. ${ }^{50}$ Lima syarat pertama dari delapat syarat tersebut diperoleh melalui pendidikan. Pada abad ke18-19, ada dua institusi penting yang mendukung kepujanggaan yaitu keluarga dan pesantren. ${ }^{51} \mathrm{Jadi}$, pengiriman calon pujangga untuk belajar ilmuilmu agama sebenarnya bisa ke semua pesantren dan tidak harus ke Pesantren Tegalsari. Tetapi karena Pesantren Tegalsari adalah lembaga pendidikan paling masyhur pada abad 18-19, maka pesantren inilah yang menjadi tujuan utama para pujangga senior dalam menyekolahkan anak-anaknya.

Kiai Ilyas wafat pada tahun 1800. Meninggalnya Kiai Ilyas menyisakan sedikit konflik tentang suksesi kepemimpinan di Tegalsari. Tegalsari diperebutkan oleh tiga orang putranya sehingga harus ada pembagian hak untuk menghindari konflik. Hasilnya adalah, Kiai Kasan Anom mendapat bagian sebagai pemimpin tanah perdikan, Mukibat mendapat jatah sebagai Kepala Desa, dan Kiai Ageng Kasan Besari sebagai pimpinan pesantren. ${ }^{52}$

\section{G. Sikap dan Manuver Politik Kiai Kasan Besari (1800-1862)}

Awal masa kepemimpinan Kiai Kasan Besari tampak normal. Perpolitikan Kasunanan Surakarta juga relatif masih stabil karena pada masa itu konflik politik bergeser ke Kasultanan Yogyakarta. Daerah Tegalsari sendiri masuk dalam daerah mancanegara dari Kasunanan Surakarta, sehingga tidak ada dampak langsung antara konflik di Yogyakarta dengan aktifitas di Pesantren Tegalsari.

Keadaan mulai berubah ketika memasuki tahun 1925, dimana Perang Jawa yang dikobarkan oleh Pangeran Diponegoro meletus pada tahun tersebut. Perang Jawa didengungkan oleh Pangeran Diponegoro sebagai perang sabil (perang suci), karena tujuan dari perang adalah untuk untuk melawan orang-

${ }^{50}$ R. Ng. Ranggawarsita, Wirid Hidajat Djati (Surabaya: Trimurti, 1954), 15-6.

51Margana, Pujangga Jawa Dan Bayang-Bayang Kolonial (Yogyakarta: Pustaka Pelajar, 2004), 130. Dalam buku ini Margana menjelaskan bahwa prawira juga bisa didapatkan dari pendidikan pesantren.

${ }^{52}$ Guillot, “Le Rôle Historique,” 145. 
orang kafir dan memperjuangkan restorasi keluhuran kedudukan agama Islam di Jawa. Diponegoro mencita-citakan pemulihan atau restorasi tata nilai moral yang lebih luas dengan gerakan yang nyata, daripada sekedar mendakwahkan ajaran agama Islam secara lisan. Tindakan ini dilakukan oleh sang Pangeran setelah melihat kesenjangan sosial-ekonomi yang begitu tajam antara rakyat dengan kaum elit, baik dari kalangan keraton maupun penjajah Belanda. Selain itu, isu korupsi yang dilakukan di tengah penderitaan rakyat oleh oknum aristokrat kasultanan, semisal Danurejo IV, juga menjadi salah satu faktor pemicu pecahnya perang. Tujuan inilah yang menyebabkan Pangeran Diponegoro dengan cepat menyatukan berbagai elemen masyarakat, dari golongan bangsawan sampai kaum buruh, dalam satu gerakan bersama. ${ }^{53}$ Salah satu elemen dalam masyarakat yang diajak untuk bergabung, dan memiliki andil besar, dalam perang suci ini adalah kaum pesantren.

Pesantren menjadi salah satu kekuatan terpenting bagi Pangeran Diponegoro ketika mengobarkan Perang Jawa. Persamaan ideologi dan cita-cita antara Pangeran Diponegoro dan kaum santri adalah alasan mengapa pesantren menjadi elemen terpenting dalam menopang kesuksesan perang. Oleh karena itu, Pangeran Diponegoro dan beberapa panglima perangnya menghimpun kekuatan dengan mengajak kiai-kiai pesantren untuk terlibat aktif dalam melawan orang Eropa kapir laknatullah (kafir yang dilaknat Allah) dan kapir murtad (orang murtad, orang Jawa yang memihak Belanda). ${ }^{54}$

Berdasarkan konsep Perang Jawa di atas, maka tidak heran apabila Pesantren Tegalsari kemudian diajak untuk terlibat aktif dalam perang suci. Tepatnya tahun 1828, Sasradilaga, atas nama Pangeran Diponegoro, datang ke Pesantren Tegalsari untuk meminta dukungan kepada Kiai Kasan Besari.55 Momen ini menjadi krusial bagi sang Kiai karena harus berdiri di antara dua pilihan yang sama-sama sulit, yaitu ikut bertempur demi tegaknya Islam di tanah Jawa dengan resiko hancurnya Pesantren Tegalsari apabila kalah, atau tidak ikut berperang dengan resiko dituduh mencari posisi aman.

Kiai Kasan Besari kemudian memilih untuk mengambil jalan tengah dengan langkah ideologis nonpraktis. Artinya, Kiai Kasan Besari tidak mau terlibat dalam peperangan fisik, tetapi secara moral dan ideologis sepenuhnya

\footnotetext{
${ }^{53}$ Carey, Takdir, xxxv-xxxvi.

${ }^{54}$ Carey, Takdir, xxxvii..

${ }^{55}$ Guillot, "Le Rôle Historique," 148.
} 
memberikan dukungan kepada Pangeran Diponegoro. Pilihan ini diambil karena dua alasan: 1) Menjaga eksistensi Pesantren Tegalsari dan 2) menjaga sosialekonomi masyarakat Desa Tegalsari. Dua alasan ini hampir sama dengan alasan Kiai Ageng Mohamad Besari yang tidak mau terlibat dalam Perang Suksesi Jawa III. Kiai Kasan Besari konsisten untuk melaksanakan garis politik pesantren untuk sepenuhnya mendidik dan mengayomi masyarakat tanpa harus terjun dalam politik praktis.

Sikap dari Kiai Kasan Besari ini bisa saja menuai tudingan miring bahwa dia hanya cari aman sendiri. Tetapi sampai saat ini tidak ditemukan bukti atau sumber yang menunjukkan adanya kemarahan atau ketidaksukaan masyarakat terhadap sikap dari Kiai Kasan Besari. Begitu pula dengan sikap Sasradilaga atas ditolaknya ajakan untuk bergabung dalam Perang Jawa, tidak ada data tentang respon dari pihak yang terlibat perang atas sikap sang Kiai.

Kemungkinan terkait tidak adanya respon dari pihak yang terlibat perang atas sikap Kiai Kasan Besari adalah karena Pesantren Tegalsari masuk dalam teritorial Kasunanan Surakarta, sementara semangat Perang Jawa adalah akibat dari dekadensi moral yang terjadi di Kasultanan Yogyakarta. Tokoh-tokoh Perang Jawa juga yang didominasi oleh keluarga dan loyalis Pangerang Diponegoro yang berasal dari Kasultanan Yogyakarta. Meskipun Perang Jawa diklaim sebagai perang suci, tetapi sebutan itu merupakan klaim sepihak dari Pangeran Diponegoro yang tentu masih bisa diperdebatkan oleh para ulama. Terlebih lagi Tegalsari memiliki status tanah perdikan dari Kasunanan Surakarta, yang secara politis dimaknai sebagai politik pengurungan (contaiment policy) dari Kasunanan untuk mengendalikan ulama dan basis massa agar tidak memerankan diri sebagai oposisi.56 Dari sudut ini, penolakan Kiai Kasan Besari dapat dimaklumi sehingga tidak ada pihak yang menyimpan kemarahan atas sikap sang Kiai.

Terlepas dari pro dan kontra atas sikap Kiai Kasan Besari di Perang Jawa, tetapi ternyata semakin banyak masyarakat yang menaruh simpati kepada sang Kiai. Politik kerakyatan yang diterapkan oleh Kiai Kasan Besari ternyata juga dapat mendongkrak popularitas sang Kiai dan Pesantren Tegalsari yang dia pimpin. Politik kerakyatan ini pula yang kemudian dimanfaatkan oleh banyak

56Hermanu Joebagio, "Politik Islam dalam Pusaran Sejarah Surakarta," Millah: Jurnal Studi Agama 13, no. 1 (2013): 164. 
orang untuk berlindung dari kebijakan tanam paksa yang dikeluarkan oleh pemerintah kolonial setelah Perang Jawa selesai. ${ }^{57}$ Status sebagai tanah perdikan yang dimiliki oleh Tegalsari menyebabkan desa ini tidak terkena dampak kebijakan tanam paksa. Kondisi ini dimanfaatkan (disalahgunakan) banyak orang, selain perlindungan dari Kiai Kasan Besari, dengan berpindah menjadi penduduk Desa Tegalsari, sehingga mengakibatkan kenaikan populasi yang tidak wajar di desa perdikan tersebut. ${ }^{58}$

Meskipun dipenuhi dengan gejolak, tidak dapat dipungkiri bahwa masa kepemimpinan Kiai Kasan Besari ini merupakan puncak kejayaan dari Pesantren Tegalsari. Pesantren Tegalsari menjadi sebuah lembaga yang multifungsi, tidak saja sebagai lembaga pendidikan-keagamaan tetapi menjelma sebagai tempat untuk mencari legitimasi, baik secara sosial, akademik, maupun politik. Sebuah kejayaan yang belum pernah dicapai oleh dua kiai sebelumnya, dan tidak pula dapat dilanjutkan oleh kiai-kiai setelahnya.

\section{H. Kesimpulan}

Kesimpulan dari penelitian ini adalah:

Pertama, Pesantren Tegalsari adalah salah satu pesantren tertua di Indonesia yang didirikan oleh Kiai Ageng Mohamad Besari pada paruh pertama abad ke-18. Pesantren Tegalsari adalah embrio dari lembaga pendidikan pesantren yang berdiri pada masa setelahnya, dengan mempelopori pendidikan 24 jam sebagai upaya sistematisasi institusi pesantren.

Kedua, Pesantren Tegalsari menjadi saksi atas konflik multidimensional di Jawa abad 18-19. Beberapa peristiwa yang melibatkan Pesantren Tegalsari antara lain pengungsian Pakubuwana II ke Tegalsari ketika tejadi geger pacina tahun 1742, permintaan dukungan dari Pangeran Mangkubumi kepada Kiai Ageng Mohamad Besari ketika Perang Suksesi Jawa III tahun 1746-1755, dan

\footnotetext{
57Untuk memenangkan Perang Jawa, Belanda harus kehilangan 25 juta gulden. Jumlah ini sangat menguras kas pemerintah kolonial. Untuk menutupnya, pemerintah kolonial di bawah kepemimpinan Johannes van den Bosch menerapkan kebijakan tanam paksa (1830-1870). Lihat: Carey, Takdir, xxxii.

58Peristiwa ini pula yang menjadi awal dari dilucutinya kawasan perdikan Tegalsari oleh pemerintah kolonial Hindia-Belanda. Tetapi Belanda baru berani melucuti Desa Tegalsari, dengan memecahnya menjadi beberapa desa dengan beberapa fungsi, setelah Kiai Kasan Besari wafat tahun 1862. Lihat: Guillot, “Le Rôle Historique,” 150.
} 
permintaaan dukungan dari Sasradilaga kepada Kiai Kasan Besari ketika Perang Jawa tahun 1825-1830.

Ketiga, Kiai Ageng Mohamad Besari (1742-1773) sebagai pendiri Pesantren Tegalsari meletakkan dasar politik pesantren sebagai lembaga pendidikan yang terbebas dari politik praktis. Garis politik ini diterapkan oleh Kiai Ageng Mohamad Besari ketika berhasil membantu Pakubuwana II secara spiritual untuk menyelesaikan geger pacina di Kartasura. Keberhasilan ini secara tidak langsung menaikkan daya tawar Pesantren Tegalsari, sekaligus membuka kesempatan bagi Kiai Ageng Mohamad Besari untuk masuk dan ikut dalam kontestasi politik keraton. Tetapi kesempatan itu tidak digunakan oleh sang Kiai yang lebih memilih untuk tetap menjadi pendidik di pesantren.

Keempat, Kiai Ilyas (1773-1800) melanjutkan politik pesantren yang sudah digariskan oleh ayahnya. Kiai Ilyas dengan cerdik memanfaatkan stabilitas politik yang ada pada waktu itu untuk membangun tradisi intelektual di Pesantren Tegalsari. Berkat usaha dari Kiai Ilyas, Pesantren Tegalsari kemudian terkenal sebagai tempat untuk belajar agama bagi para calon pujangga. Sastranegara, sebelum dinobatkan menjadi pujangga dengan nama Yasadipura II, adalah orang pertama yang mengawali tradisi ini.

Kelima, masa keemasan dari Pesantren Tegalsari sekaligus masa penuh gejolak terjadi ketika Kiai Kasan Besari (1800-1862) tampil sebagai pimpinan pesantren. Pada masa kepemimpinannya, Pesantren Tegalsari berusaha dilibatkan oleh Sasradilaga dalam Perang Jawa yang diklaim oleh Pangeran Diponegoro sebagai perang suci. Kiai Kasan Besari kemudian menyikapinya dengan mengambil langkah ideologis nonpraktis. Artinya, Kiai Kasan Besari tidak mau terlibat dalam peperangan fisik, tetapi secara moral dan ideologis sepenuhnya memberikan dukungan kepada Pangeran Diponegoro. Pilihan ini diambil karena dua alasan: (1) Menjaga eksistensi Pesantren Tegalsari dan (2) menjaga sosial-ekonomi masyarakat Desa Tegalsari.[] 


\section{DAFTAR PUSTAKA}

Baso, Ahmad. "Akar Pendidikan Kewarganegaraan di Pesantren." Jurnal Pendidikan Islam 17, no. 2 (2012): 161-86. https://doi.org/10.15575/ jpi.v27i2.503.

Bruinessen, Martin van. Contemporary Developments in Indonesian Islam: Explaining the Conservative Turn. Singapore: ISEAS Publishing, 2013.

Carey, Peter. Takdir: Riwayat Pangeran Diponegoro 1785-1855. Jakarta: Kompas, 2017.

Djakfar, Muhammad. Etika Bisnis: Menangkap Spirit Ajaran Langit dan Pesan Moral Ajaran Bumi. Jakarta: Penebar Plus+, 2012.

Djody, Setiawan. Reformasi dan Elemen-elemen Revolusi. Jakarta: 2009.

Djuhan, Muhammad Widda. "Ritual di Makam Ki Ageng Besari Tegalsari Jetis Ponorogo." Kodifikasia 5, no. 1 (2011): 169-86.

Fauziyyah, Fida Indra, Warto, and Sariyatun. “Ronggowarsito's Concept of Islamic Theosophy in Serat Sabdajati." International Journal of Multicultural and Multireligious Understanding 5, no. 2 (2018): 177-84. http://ijmejournal.org/index.php/ijme/pages/view/SpecialIssue2017.

Florida, Nancy K. Javanese Literature in Surakarta Manuscripts Vol II: Manuscripts of The Mangkunagaran Palace. Itacha: Cornell University Press, 2000.

Fokkens, F. "De Priesterschool Te Tegalsari.” Tijdschrift Voor Indische Taal, LandEn Volkenkunde, no. Deel 24 (1877).

Guillot, Claude. “Le Dluwang Ou: Papier Javanais.” Archipel 26 (1983): 105.

- _- "Le Rôle Historique Des Perdikan Ou Villages Francs: Le Cas de Tegalsari." Archipel 30 (1985): 142.

Haji, Haris Daryono Ali. Menggali Pemerintahan Negeri Doho, dari Majapahit menuju Pondok Pesantren, sebelum Walisongo dan Babad Pondok Tegalsari. Yogyakarta: Elmatera, 2016.

Hatley, Barbara. Javanese Performances on an Indonesian Stage: Celebrating Culture, Embracing Change. Singapore: NUS Press, 2008. 
Joebagio, Hermanu. "Politik Islam dalam Pusaran Sejarah Surakarta." Millah: Jurnal Studi Agama 13, no. 1 (2013): 155-77.

Katno. "Penerapan Hukum Islam di Keraton Kasunanan Surakarta Masa Pakoe Boewono IV (Tahun 1788-1820 M)." Profetika: Jurnal Studi Islam 16, no. 1 (2015): 46-70.

Kumite Ranggawarsitan. Serat Babad Cariyos Lelampahanipun Suwargi Raden Ngabei Ranggawarsita. Surakarta: Drikerei Mares, 1933.

Kusnanto, Hadi, and Yudi Hartono. "Masjid Tegalsari Jetis Ponorogo (Makna Simbolik dan Potensinya sebagai Sumber Pembelajaran Sejarah Lokal)." Gulawentah: Jurnal Studi Sosial 2, no. 1 (2017): 41-48.

Lindert, Peter H. Shifting Ground: The Changing Agricultur Soils of China and Indonesia. London: The MIT Press, 2000.

Lombard, Denys. Nusa Jawa: Silang Budaya III - Warisan Kerajaan-Kerajaan Konsentris. terj. Winarsih P. Arifin. Jakarta: Gramedia Pustaka Utama, 2005.

Majid, Nurcholis. Bilik-bilik Pesantren: Sebuah Potret Perjalanan. Jakarta: Paramadina, 1997.

Margana. Pujangga Jawa dan Bayang-bayang Kolonial. Yogyakarta: Pustaka Pelajar, 2004.

Martin Van Bruinessen. Kitab Kuning, Pesantren, dan Tarekat: Tradisi-tradisi Islam di Indonesia. Bandung: Mizan, 1995.

Moesa, Ali Maschan. Nasionalisme Kiai: Konstruksi Sosial Berbasis Agama. Yogyakarta: LKiS, 2007.

Mu'tasim, Radjasa, Timbul Haryono, and St. Sunardi. Agama dan Pariwisata. Yogyakarta: Pustaka Pelajar, 2013.

Muljana, Slamet. Runtuhnya Kerajaan Hindu-Jawa dan Timbulnya Negara-negara Islam di Nusantara. Yogyakarta: LKiS, 2005.

Multazam, Dawam. "The Dynamics of Tegalsari (Santri and Descendants of Pesantren Tegalsari Ponorogo Kiai's in 19-20th)." Qalamuna 9, no. 1 (2017): 91-110.

Pakêmpalan Ngarang Serat ing Mangkunagaran. Serat Babad Panambangan. Surakarta: Indonesise Drikkere, 1918.

Ranggawarsita, R. Ng. Wirid Hidajat Djati. Surabaya: Trimurti, 1954. 
Reid, Anthony. Asia Tenggara dalam Kurun Niaga 1450 - 1680 Jilid 2: Jaringan Perdagangan Global. Jakarta: Yayasan Pustaka Obor Indonesia, 2011.

Remmelink, Willem G.J. Perang Cina dan Runtuhnya Negara Jawa, 1725-1743. terj. Akhmad Santoso. Yogyakarta: Jendela, 2002.

Ricklefs, Merle Calvin. Sejarah Indonesia Modern 1200-2008. Jakarta: Serambi Ilmu Semesta, 2008.

Rohmatulloh, Dawam M. "Local Muslim Heritage: Pelestarian Warisan Budaya Pesantren di Tegalsari Ponorogo." Proceedings Second Annual Conference For Muslim Scholars Dengan Tema "Strengthening The Moderate Vision of Indonesian Islam, no. April (2018): 232-39.

Sahal, Husni, and Alhafiz K. "Ini Penjelasan Agus Sunyoto tentang Hubungan Pesantren Dan Keraton." NU Online: Soeara Nahdlatoel Oelama, 2017. http://www.nu.or.id/post/read/79995/ini-penjelasan-agus-sunyototentang-hubungan-pesantren-dan-keraton.

Sasrasumarta, R. Tus Pajang. Surakarta: Budi Utama, 1939.

Sears, Laurie Jo. Shadows of Empire: Colonial Discourse and Javanese Tales. London: Duke University Press, 1996.

Silsilah Kyai \& Nyai Ageng Anom Besari. Madiun, t.th.

Solahudin, Dindin. The Workshop for Morality: The Islamic Creativity of Pesantren Daarut Tauhid in Bandung Java. Canberra: ANU E Press, 2008.

Teygeler, R. "Dluwang, a Near-Paper from Indonesia." dalam IPH Congress Book 1996, 11:134-45. Marburg: International Association of Paperhistorians, 1996.

Tilaar, H.A.R. Paradigma Baru Pendidikan Nasional. Jakarta: Rineka Cipta, 2002.

Turmudi, Endang. Perselingkuhan Kiai dan Kekuasaan. Yogyakarta: LKiS, 2004.

Umar, Nasaruddin. Rethinking Pesantren. Jakarta: Elex Media Komputindo (Quanta), 2014.

Wacono, Setyo. keturunan ketujuh dari Kiai Ageng Mohamad Besari. Wawancara. Rabu 7/2/2018. 